\title{
Agronomy Journal
}

\section{EFFECT OF NITROGEN AND ENDOPHYTIC BACTERIA ON BIOPHYSICAL AND SPECTRAL PARAMETERS OF WHEAT CANOPY}

\begin{tabular}{|r|l|}
\hline Journal: & Agronomy Journal \\
\hline Manuscript ID: & AJ-09-0087-A.R4 \\
\hline Manuscript Type: & Article \\
\hline Keyword: & Nitrogen, Remote sensing, geophysical instrumentation, Wheat \\
\hline Table of Contents Heading: & Remote Sensing \\
\hline \multicolumn{2}{|l}{} \\
\hline
\end{tabular}

\section{S ScholaroNE \\ Manuscript Central}




\title{
EFFECT OF NITROGEN AND ENDOPHYTIC BACTERIA ON BIOPHYSICAL AND SPECTRAL PARAMETERS OF WHEAT CANOPY
}

\author{
M. Adami, B.F.T. Rudorff,* F.M. Breunig, F.J. Ponzoni, L.S. Galvão, M.A. Moreira, J.G. \\ Freitas, and V. Marino Rodrigues Sala
}

M. Adami, B.F.T. Rudorff, F.M. Breunig, F.J. Ponzoni, L.S. Galvão, and M.A. Moreira, Divisão de Sensoriamento Remoto, Instituto Nacional de Pesquisas Espaciais - INPE - P.O. Box 515-12245-970, São José dos Campos, São Paulo State, Brazil; J.G. Freitas and V. Marino Rodrigues Sala, Instituto Agronômico de Campinas-IAC, P.O. Box 28, 13012970, Campinas, São Paulo State, Brazil. Received 2 Mar. 2009. *Corresponding author (bernardo@dsr.inpe.br).

\begin{abstract}
Nitrogen (N) is the primary limiting factor to increase wheat (Triticum aestivum L.) yield in Brazil and the use of $\mathrm{N}$ fixing agents might be an alternative to increase wheat production. A field experiment was conducted in 2006 in São Paulo state, Brazil, with three N rates $\left(0,60\right.$ and $\left.120 \mathrm{~kg} \mathrm{ha}^{-1}\right)$ and three endophytic bacteria (IAC-HT-11; IAC-HT-8; and IACAT-8) (1) to evaluate their combined impact on biophysical (LAI and grain yield) and spectral parameters (NDVI, absorption band parameters) of wheat and (2) to determine the spectral parameters that best correlated with LAI and grain yield. LAI and canopy spectral reflectance measurements were made at jointing, heading and ripening growth stages for this purpose. The statistical relationships between biophysical and spectral parameters were evaluated within and among the treatments. Statistical results showed that the $\mathrm{N}$ rates significantly affected both biophysical and spectral parameters as expected. Bacteria inoculation presented a significant effect only on grain yield and is consistent with results reported in the literature. The NDVI followed by absorption band parameters $P_{B}$ and $A_{B}$ at $1205 \mathrm{~nm}$ provided best estimates of LAI and grain yield during the heading stage indicating that it may be the best stage for remote sensing based yield mapping.
\end{abstract}

Keywords: field spectroradiometry, remote sensing, reflectance, NDVI, LAI.

\section{INTRODUCTION}

Nitrogen $(\mathrm{N})$ is considered as the primary limiting factor to increase wheat (Triticum aestivum 
L.) yields in Brazil (Sala et al., 2005). In search for alternatives that would reduce this limitation, research has been conducted with endophytic bacteria and fungi as nitrogen fixing agents for wheat plant while the plant is furnishing energy for bacteria or fungi metabolism (Conn, 2005; Sala et al., 2005; Larran et al., 2007). The endophytic bacteria and fungi remain within the living plant tissue for part or all of their life cycle, increasing $\mathrm{N}$ availability without causing visible symptoms of infection (Conn and Franco, 2004; Kizilkaya, 2008). Rodrigues et al. (2000) showed an increase in $\mathrm{N}$ content in the grain with bacteria inoculation and no improvement in wheat yield. Sala et al. (2007) reported that wheat inoculated with nitrogen fixing bacteria with no additional $\mathrm{N}$ application increased biomass and grain yield. According to Freitas (2000), practical use of bacteria as inoculants still requires more experiments because their effects on yield and $\mathrm{N}$ assimilation of wheat are not well understood. Increase in $\mathrm{N}$ concentration of wheat produces spectral reflectance changes that may be detected by remote sensing instruments, as demonstrated by several researchers (Serrano et al. 2000; Mullen et al., 2003; Pena-Yewtukhiw et al., 2006; Shou et al., 2007; Sripada et al., 2007; Tilling et al., 2007; Feng et al., 2008). If bacteria treatment affects yield and $\mathrm{N}$ assimilation of wheat, it may affect their relationships with spectral parameters. However, bacteria inoculation effects on wheat reflectance have not been reported in the literature.

From a remote sensing perspective, plants absorb more solar energy in the visible region with increasing biomass. In the near-infrared region, they reflect and transmit more energy due to increase in the multiple scattering and transmission of radiation that occur on both individual leaves and the entire plant canopy (Goel, 1988). As a result, vegetation indices such as the normalized difference vegetation index (NDVI), the most frequently used spectral vegetation index, are usually correlated with leaf area index (LAI) and crop yield (Aparicio et al., 2000; Serrano et al., 2000; Thenkabail et al., 2000; Elwadie et al., 2005; Eitel et al., 2008; Raun et al., 2008; Galvão et al., 2009).

Advances in the hyperspectral remote sensing technology are driving the development of new analytical methods that consider not only the vegetation indices to estimate biophysical parameters, but also the continuous and individual features of reflectance spectra (Meer, 2000; Wiegand et al., 2001). For example, absorption bands associated with the chlorophyll (665 $\mathrm{nm}$ ) and leaf water content (982 and $1205 \mathrm{~nm}$ ) can be measured by laboratory, field, airborne or orbital non-imaging and imaging spectrometers. Such features can be extracted from spectra using the continuum removal method (Clark and Roush, 1984), which allows the subsequent determination of the depth $\left(P_{B}\right)$ and area $\left(A_{B}\right)$ of each absorption band (Meer, 2000; Mutanga et al., 2003). Leaf water absorption bands may also be correlated with LAI 
(Gao, 1996) and crop yield (Galvão et al., 2009). Despite these advances most of the studies to determine biophysical parameters of wheat are still based on vegetation indices (e.g., Mullen et al., 2003; Wu et al., 2008). Only a few works have addressed spectral feature analysis for this purpose (Zhao et al., 2004; Delegido et al., 2008), and none of them has compared the performance of vegetation indices and absorption band parameters calculated from the continuum removal method to estimate LAI and yield.

The objectives of this field experiment were: (1) to evaluate the combined impact of three rates of $\mathrm{N}$ and three endophytic bacteria treatments on biophysical (LAI and grain yield) and spectral parameters (NDVI, absorption band parameters) of wheat (Triticum aestivum L.); and (2) to determine the spectral parameters that best correlated with LAI and grain yield.

\section{METHODS}

\section{Experiment}

This experiment was conducted at the research farm of the Agronomic Institute of Campinas located in the Campinas municipality, São Paulo State, Brazil (22 $51^{\circ} 53^{\prime \prime} \mathrm{S}$ and 47 04' 52" W). Wheat plants were grown from June to September of 2006. According to the Köppen classification, the climate of this region is Cwa (humid subtropical with dry winter). During the growing season, the mean temperature was $18.4,18.7,20.5$ and $20.9{ }^{\circ} \mathrm{C}$ in June, July, August, and September, respectively. The monthly precipitation in June, July, August, and September was 22.5, 48.8, 12.4 and $101.9 \mathrm{~mm}$, respectively. This pattern was close to normal conditions for this region. The average water demand for wheat is $4 \mathrm{~mm}$ per day; therefore, water was supplemented with irrigation. Canopy reflectance, LAI and yield data were collected for each wheat plot treated with different endophytic bacteria and $\mathrm{N}$ rates. The experimental design was a factorial randomized complete block with six replications of treatments that were applied to a single wheat cultivar (IAC-370 Triticum aestivum L.) and consisted of one control and three isolates of endophytic bacteria (B0 - without bacteria or control; B1 - IAC-HT-11 of Herbaspirillum spp.; B2 - IAC-HT-8 of Herbaspirillum spp.; and B3 - IAC-AT-8 of Azospirillum spp.), and three rates of N as urea at 0,60 and $120 \mathrm{~kg} \mathrm{ha}^{-}$ ${ }^{1}$, denoted as N0, N60, and N120, respectively. According to Baldani and Baldani (2005), it is important to select the most appropriated endophytic diazotrophic bacterium for each crop.

The application of endophytic bacteria was achieved using $2 \mathrm{~g}$ of powdered peaty inoculum per $150 \mathrm{~g}$ of seeds. Each gram of inoculum contained a bacteria population of $10^{9}$. Wheat was sown on June 5, 2006 with 80 viable seeds per meter and seedlings were emerged on June 11, 
2006. Planting rows were oriented east-west ( $80^{\circ}$ azimuth) and were spaced on $0.2 \mathrm{~m}$. Plots were $5.0 \mathrm{~m}$ long and $1.2 \mathrm{~m}$ wide. According to the fertilizer recommendations, $1 / 3$ of the total $\mathrm{N}$ dosage was applied at planting and the remaining $2 / 3$ was applied as top dressing on July 20, 2006. Based on the soil test, phosphorus (P) and potassium (K) were applied at a rate of $200 \mathrm{~kg} \mathrm{ha}^{-1}$ using 0-20-20 N-P-K (Raij et al., 1997).

\section{Reflectance factor and LAI}

Remote sensing data consisted of conical-directional reflectance factor spectra collected using a FieldSpec Pro FR portable field spectroradiometer (Analytical Spectral Devices Inc., 2006), which operates from 350 to $2500 \mathrm{~nm}$ wavelengths of the electromagnetic spectrum. A $25^{\circ}$ field of view lens was used, positioned at nadir $0.76 \mathrm{~m}$ above the canopy, defining an area of approximately $900 \mathrm{~cm}^{2}$ above the canopy. The spectral resolution varies from $3 \mathrm{~nm}$ (350-700 $\mathrm{nm})$ to $10 \mathrm{~nm}(700-2500 \mathrm{~nm})$. Radiometric measurements were taken at about 11:00 a.m. using the following protocol: a) signal-to-noise optimization as a function of change in radiance measured on a reference panel (Spectralon); b) reading radiance from the reference panel; and c) reading radiance from the canopy of each plot. The conical-directional reflectance factor $(\rho)$ was obtained from these measurements, which is the ratio between the spectral radiance of the canopy and the spectral radiance of the reference panel, maintained under the same conditions of illumination and target geometry (Milton, 1987). No smoothing procedure was applied after data collection. Due to poor signal-to-noise ratio, noisy data associated with the $1350-1450 \mathrm{~nm}, 1750-2020 \mathrm{~nm}$ and $2350-2500 \mathrm{~nm}$ spectral intervals were omitted from the analysis.

Non-destructive LAI measurements were performed early in the morning (more diffuse and less direct solar radiation) with a LAI-2000 Plant Canopy Analyzer (LI-COR Biosciences Inc., 2006). Radiometric as well as LAI measurements were made on three dates: 1) July 21, 2006 when the second node of the wheat plants become visible (jointing; Feekes 7.0); 2) August 4, 2006 when the awns were visible and the heads were emerging through the slit of flag leaf sheath (heading; Feekes 10.1); and 3) August 21, 2006 when grains became milky ripe (ripening; Feekes 11.1), according to the growth stage description for cereals given by Large (1954).

\section{Continuum removal}

Continuum removal is a technique proposed by Clark and Roush (1984) that consists of normalizing the absorption features of the reflectance spectrum by using a straight line 
(continuum), which delimits the edges of absorption features (Figure 1).

Figure 1

The mathematic formula for continuum removal of the reflectance spectrum is given in Equation 1 (Clark and Roush, 1984):

$$
\rho_{C R \lambda}=\frac{\rho_{\text {original } \lambda}}{\rho_{\text {continum } \lambda}},
$$

where $\lambda$ is the wavelength; $\rho_{\mathrm{CR}}$ is the normalized conical-directional reflectance factor, that is, with the continuum removed; $\rho_{\text {original }}$ is the original conical-directional reflectance factor; and $\rho_{\text {continum }}$ is the conical-directional reflectance factor of the continuum line.

The continuum line can be expressed mathematically by a linear equation (Equation 2), where slope (k) is obtained from Equation 3 and where y-intercept $(w)$ is obtained from Equation 4, adjusted to the upper and lower limits (user defined) of each absorption band,

$$
\begin{gathered}
\rho_{\text {continuum } \lambda}=w+k \lambda \\
k=\frac{\rho_{\text {original }(M)}-\rho_{\text {original }(m)}}{\lambda_{M}-\lambda_{m}} \\
w=\frac{\left\lfloor\rho_{\text {original }(m)} \cdot\left(\lambda_{M}-\lambda_{m}\right)\right\rfloor+\left\lfloor-\lambda_{m} \cdot\left(\rho_{\text {original }(M)}-\rho_{\text {original }(m)}\right)\right\rfloor}{\lambda_{M}-\lambda_{m}},
\end{gathered}
$$

Eq. 2

where $M$ and $m$ represent the upper and lower limits, respectively, of the absorption band under analysis. Other details of continuum removal can be found in Clark and Roush (1984), Kokaly and Clark (1999) and Noomem et al. (2005).

After continuum removal, two spectral parameters (band depth $P_{B}$ and band area $A_{B}$ ) can be obtained (Figure 1). $P_{B}$ is calculated from the definition of the position of the reference $\lambda$ ( $\lambda_{\text {reference }}$ ) from which $P_{B}$ is measured. One way to define $\lambda_{\text {reference }}$ consists of locating the $\lambda$ at which the greatest depth occurs (least $\rho_{C R}$ value). Another way is to adopt a $\lambda_{\text {reference }}$ value from the literature. In this study, the lower limit $(m)$, the upper limit $(M)$ and the $\lambda_{\text {reference, for }}$ each absorption band, were defined based on Gao (1996), Curran et al. (2001), Schmidt and Skidmore (2003), and Galvão et al. (2005) and are given in Table 1. The absorption band depth $\left(P_{B}\right)$ is the distance between $\rho_{\text {continuum }}(=1)$ and $\rho_{P C R}$ at the position of $\lambda_{\text {reference }}$ (Equation 5): 


$$
P_{B}=1-\rho_{C R \lambda}
$$

\section{Table 1}

The absorption band area $\left(A_{B}\right)$ is formed by both the $\rho_{\text {continum }}$ line as by the $\rho_{C R}$ band (Figure 1c) and is calculated through numerical approximation (Equation 6), which considers the area of the trapezoid in each interval of $\lambda$ measured by the sensor between the limits $m$ and $M$ shown in Table 1.

$$
A_{B}=\sum_{i=m}^{M} \frac{\left(\rho_{i}+\rho_{i-1}\right)}{2} \cdot\left(\lambda_{i}-\lambda_{i-1}\right)
$$

where $A_{B}$ is the absorption band area, and $i$ represents the $\lambda$ interval measured by the sensor along the spectrum between the absorption band limits $m$ and $M$ (Table 1). It should be emphasized that the $\lambda$ interval is defined by the spectral resolution of the sensor.

In the present study, the NDVI was calculated using Equation 7, as described by Daughtry et al. (2000):

$$
N D V I=\frac{\rho_{801}-\rho_{670}}{\rho_{801}+\rho_{670}},
$$

where $\rho_{801}$ and $\rho_{670}$ represent the conical-directional reflectance factors measured at $801 \mathrm{~nm}$ and $670 \mathrm{~nm}$, respectively.

\section{Statistical analysis}

In order to evaluate the impact of the different $\mathrm{N}$ and endophytic bacterial treatments on the biophysical parameters (LAI and grain yield) and spectral parameters $\left(A_{B}, P_{B}\right.$ and NDVI), the following statistical procedures were used: (a) Bartlett's test to confirm homoskedasticity; (b) analysis of variance (ANOVA) to determine whether treatment means differed from each other; and (c) Tukey's test to identify significant differences detected by ANOVA.

To improve the precision of the correlations between biophysical and spectral parameters without using assumption for sample distribution, the bootstrapping technique (Efron, 1982) was used with 1,000 repetitions with replacement (combinations of the 72 plots). The bootstrap statistics consists of the random collection of a predetermined number of samples 
from a population for $n$ times, yielding $n$ correlations, with the objective of reducing error associated with the collection of a non-representative sample. Analyses were performed on data collected during the jointing, heading and ripening growth stages. Results from these estimates were evaluated through histograms, wherein the probability of occurrence of a result is given by the area below the curve.

\section{RESULTS AND DISCUSSION}

\section{Effects of treatments on biophysical parameters}

A preliminary analysis for variance homogeneity using Bartlett's test revealed that LAI and grain yield were homoskedastic. The ANOVA of the LAI values showed that only the $\mathrm{N}$ factor differentiated the mean values (Table 2) while Sala et al. (2007) found that both N and bacteria affected the plant dry matter weight. According to Serrano et al. (2000), LAI was strongly dependent on $\mathrm{N}$ application rates. For the jointing and ripening growth stages, the N60 and N120 treatments had a significant effect on LAI values in comparison with treatments with no $\mathrm{N}$ input. However, significant difference in LAI between the N60 and N120 treatments was observed only for the heading stage (Table 2). This behavior was probably due to differences among growth stage and the effect of additional supply of $\mathrm{N}$ on LAI became evident only at the heading stage as was also observed by Alley et al. (2009). No interaction between bacteria and $\mathrm{N}$ for LAI was observed during any of the three analyzed growth stages (Table 2).

As indicated in the last column of Table 2, bacteria, $\mathrm{N}$ rates and the interaction between these two factors affected grain yield at statistical significance levels of $1 \%, 1 \%$ and $5 \%$, respectively. The interactive effects of bacteria and $\mathrm{N}$ rates on grain yield was observed only for bacterium B2 which significantly increased grain yield in the absence of N (B2N0), as shown in Table 3. In spite of the absence of an interactive effect on LAI, the B2N0 treatment promoted a greater grain yield $\left(2046 \mathrm{~kg} \mathrm{ha}^{-1}\right)$. This might be related not only to the greater efficiency of the $\mathrm{B} 2$ bacterium in $\mathrm{N}$ fixation but also to a greater efficiency in the translocation of carbohydrates from source (leaves) to sink (grain) due to the greater amount of roots produced by B2 bacterium (Sala et al., 2007). Despite the absence of statistical significance, the same comment can be made for treatment B2N60, which produced similar grain yield. These results demonstrates the importance of the correct diazotrophic bacterium selection for each crop (Baldani \& Baldani, 2005). In N60 and N120 levels, the bacteria did not significantly affect grain yield, whose effects were probably obliterated by the greater $\mathrm{N}$ availability. Thus, $\mathrm{B} 2$ was the most adapted bacterium strain to provide $\mathrm{N}$ to wheat plants. 
Table 2

Table 3

\section{Effects of treatments on spectral parameters $\left(A_{B}, P_{B}\right.$ and NDVI)}

The preliminary analysis for variance homogeneity using Bartlett's test also revealed that $P_{B}$, $A_{B}$ and NDVI were homoskedastic. Tables 4 and 5 show results from the analysis of variance applied to $A_{B}$ and to $P_{B}$ of the three absorption bands centered at $665 \mathrm{~nm}$ (chlorophyll), 982 $\mathrm{nm}$ (leaf water) and $1205 \mathrm{~nm}$ (leaf water) for the growth stages of jointing (July 21, 2006), heading (August 4, 2006) and ripening (August 21, 2006). Table 6 presents the results for the NDVI.

The bacterial strains had no significant effect on $A_{B}, P_{B}$ or NDVI. On the other hand, $\mathrm{N}$ rates showed significant effects on these spectral parameters in all three growth stages. At jointing stage, N60 and N120 increased values of spectral parameters significantly (except $P_{B} 665 \mathrm{~nm}$ and $P_{B} 982 \mathrm{~nm}$ ). During initial development, plant growth was positively affected by increased $\mathrm{N}$ availability producing more green biomass and LAI (Serrano et al., 2000). Such an increase resulted in larger values of NDVI and in better-defined chlorophyll absorption bands and leaf water spectral features because these features are also sensitive to LAI (Gao, 1996). Consequently, the $\mathrm{N}$ levels were distinguished by most of the spectral parameters $\left(A_{B}\right.$, $P_{B}$ and NDVI). This indicated that more $\mathrm{N}$ fertilization promoted the photosynthetic activity $\left(A_{B} 665 \mathrm{~nm}\right.$ and NDVI) and a green biomass and LAI increase $\left(A_{B} 982 \mathrm{~nm}, A_{B} 1205 \mathrm{~nm}, P_{B}\right.$ $1205 \mathrm{~nm}$ and NDVI). For heading and ripening stages, only N0 was significantly different from N60 and N120 for all spectral parameters (Tables 4, 5 and 6).

Both $A_{B}$ and $P_{B}$ values were smaller during ripening stage (Tables 4 and 5), in which wheat onset its senescence (Mutanga et al., 2003). While $P_{B}$ separated N0 from both N60 and N120 in the jointing stage, but $A_{B}$ allowed to differentiate at all $\mathrm{N}$ levels. Since $\mathrm{A}_{\mathrm{B}}$ is related to the depth and width of each absorption band, results indicated that increased $\mathrm{N}$ levels produced deeper and broader absorption features. Thus, the absorption band at a specific wavelength $\left(\mathrm{P}_{B}\right)$ was less sensitive to $\mathrm{N}$ than the absorption band at a broader spectral interval $\left(\mathrm{A}_{\mathrm{B}}\right)$.

The $P_{B}$ and $A_{B}$ values in the $982 \mathrm{~nm}$ and $1205 \mathrm{~nm}$ leaf water absorption bands first increased in both jointing and heading stages, and then decreased during the ripening stage as expected (Tables 4 and 5). This behavior was slightly different for the chlorophyll absorption band (665 $\mathrm{nm}$ ) that presented slightly larger $P_{B}$ and $A_{B}$ values in the jointing stage than in the heading. Similar behavior was observed for NDVI (Table 6). This fact might be attributed to the 
significant $\mathrm{N}$ effect observed during the jointing stage. Both the $665 \mathrm{~nm}$ absorption band parameters (Tables 4 and 5) and the NDVI (Table 6) decreased towards the ripening stage as expected. During the ripening stage, the spectral reflectance of wheat canopy tends to increase in the red band due to reduced photosynthetic activity of the leaves, and decrease in the near infrared range due to reduced multiple scattering (Goel, 1988; Mutanga et al., 2003), which reduced the NDVI values. Furthermore, the ripening stage is also characterized by a decrease in the leaf water content sensed by the instrument, which produces shallower absorption bands at 982 and $1205 \mathrm{~nm}$. In general, results of Tables 4, 5 and 6 were in agreement with those reported by Mutanga et al. $(2003 ; 2005)$.

Table 4

Table 5

Table 6

\section{Correlations between biophysical and spectral parameters}

Figure 2 shows the bootstrap correlations for the relationships of LAI with $P_{B}$ values at 665 $\mathrm{nm}, 982 \mathrm{~nm}$ and $1205 \mathrm{~nm}$ and with NDVI at jointing (Figure 2a), heading (Figure 2b) and ripening (Figure 2c) growth stages. Results for the association of LAI with $A_{B}$ and NDVI values are presented in Figure 3. The $P_{B}$ is related to the energy absorbed in a specific wavelength, while $A_{B}$ comprises all the energy absorbed by crops in a broad spectral interval around the feature (Clark and Roush, 1984; Kokaly and Clark, 1999). In Figure 2, correlation values increased from the jointing to the heading stage, and then decreased in the ripening stage. The NDVI and the depth of the $1205 \mathrm{~nm}$ leaf water absorption band were strongly correlated $(\mathrm{r}=+0.80)$, which presented the largest frequency of high correlations in the heading stage. Similar results between LAI, $A_{B}$ and NDVI were observed in Figure 3 because of the expected association between $P_{B}$ and $A_{B}$.

Figure 2

Figure 3 
Figure 4 presents the distribution of correlation coefficients for the association of yield with $P_{B}$ values at $665 \mathrm{~nm}, 982 \mathrm{~nm}$ and $1205 \mathrm{~nm}$ and with NDVI at jointing (Figure 4a), heading (Figure 4b) and ripening (Figure 4c) growth stages. Results for the association of LAI with $A_{B}$ and NDVI values are illustrated in Figure 5. Differently from LAI values (Figures 2 and 3), correlations of grain yield with $P_{B}, A_{B}$ and NDVI (Figures 4 and 5) were much better (average of 0.72 for NDVI) in the heading than in the jointing stage (average of 0.54 for NDVI). In the heading stage, the range of correlation coefficients was also less variable than in the other two stages. All spectral parameters presented similar correlation results in the heading stage (Figures $4 \mathrm{~b}$ and $5 \mathrm{~b}$ ). In general, the results for yield were somewhat better than those obtained for LAI in this stage.

The mean correlation values from bootstrap analysis are shown in Table 7. In agreement with previous results, higher values of average correlation coefficients were observed in the jointing and heading stages for the relationships of LAI with NDVI and spectral parameters associated with the $1205 \mathrm{~nm}$ leaf water absorption band. For grain yield, the spectral parameters under analysis showed similar average correlations in the heading stage. Thus, the heading stage (August 4, 2006) presented the largest correlation coefficients for LAI and grain yield, which is in agreement with results obtained by Mullen et al. (2003) when studying wheat crop treated with different $\mathrm{N}$ levels.

Figure 4

Figure 5

Table 7

\section{CONCLUSIONS}

The evaluation of the impact of different $\mathrm{N}$ treatments and endophytic bacteria on biophysical (yield and LAI) and spectral (NDVI, $P_{B}$ and $A_{B}$ ) parameters of wheat showed that $\mathrm{N}$ was the most important factor. The B2 was the only bacterium to increase wheat grain yield in the absence of $\mathrm{N}$ (B2N0 treatment), which might be attributed to greater root/shoot relationship and consequent increase in translocation of carbohydrates from source to sink. However, this was not observed in the presence of N. For LAI, only N rates had a significant effect. Spectral parameters presented increased values from jointing to heading stages in response to increased $\mathrm{N}$ levels.

Comparison of the performance of NDVI and absorption band parameters showed that NDVI was the best to estimate biophysical parameters closely followed by the leaf water absorption 


\begin{abstract}
band at $1205 \mathrm{~nm}$. High values of correlation coefficients (0.70 to 0.80$)$ for LAI with spectral parameters were observed at both jointing and heading stages. For grain yield, the strong correlations were observed only at heading stage indicating that it is the best timing to acquire remote sensing data to estimate grain yield.
\end{abstract}

\title{
ACKNOWLEDGEMENTS
}

The authors are grateful to the Instituto Agronômico de Campinas (IAC) for providing the necessary conditions for the field experiment, CNPq and CAPES to the fellowship. Thanks are also due to the anonymous reviewers for very useful suggestions that improved the manuscript.

\section{REFERENCES}

Alley, M.M., P. Scharf, D.E. Brann, W.E. Baethgen, and J.L. Hammons. 2009. Nitrogen Management for Winter Wheat: Principles and Recommendations - Publication 424-026. Available at http://www.pubs.ext.vt.edu/424/424-026/424-026.pdf. (verified 10 July 2009).

Analytical Spectral Device INC. (ASD) FieldSpec® FR Portable Spectroradiometer. 2006. Available at http://www.asdi.com/products_specifications-FSP.asp (verified 3 Aug. 2006).

Aparicio, N., D. Villegas, J. Casadesus, J.L. Araus, and C. Royo. 2000. Spectral vegetation indices as nondestructive tools for determining durum wheat yield. Agron. J. 92:83-91.

Baldani, J.I., and V.L.D. Baldani. 2005. History on the biological nitrogen fixation research in graminaceous plants: special emphasis on the Brazilian experience. Anais Acad. Bras. Ciên. 77:549-579.

Clark, R.N., and T.L. Roush. 1984. Reflectance spectroscopy: Quantitative analysis techniques for remote sensing applications. J. Geophys. Res. 89:6329-6340,

Conn, V.M. 2005. Molecular Interactions of Endophytic Actinobacteria in Wheat and Arabidopsis. Doctoral Thesis. Flinders University. Adelaide, Australia.

Conn, V.M., and C.M.M. Franco. 2004. Analysis of the endophytic actinobacterial population in the roots of wheat (Triticum aestivum L.) by terminal restriction fragment length polymorphism and sequencing of 16S rRNA clones. Appl. Environ. Microbiol. 70:17871794. 
Curran, P.J., J.L. Dungan, and D.L. Peterson. 2001. Estimating the foliar biochemical concentration of leaves with reflectance spectrometry: Testing the Kokaly and Clark methodologies. Remote Sens. Environ.76:349-359.

Daughtry, C.S.T., C.L. Walthall, M.S. Kim, E. Brown de Colstoun, and J.E. McMurtrey III. 2000. Estimating corn leaf chlorophyll concentration from leaf and canopy reflectance. Remote Sens. Environ. 74:229-239.

Delegido, J., G. Fernandez, S. Gandia, and J. Moreno. 2008. Retrieval of chlorophyll content and LAI of crops using hyperspectral techniques: application to PROBA/CHRIS data. Int. J. Remote Sens. 29:7107-7127.

Efron, B. 1982. The Jackknife, the Bootstrap and Other Resampling Plans. Society for Industrial and Applied Mathematics, Philadelphia, PA.

Eitel, J.U.H., D.S. Long, P.E. Gessler, and E.R. Hunt. 2008. Combined spectral index to improve ground-based estimates of Nitrogen status in dryland wheat. Agron. J. 100:16941702.

Elwadie, M.E., F.J. Pierce, and J. Qi. 2005. Remote sensing of canopy dynamics and biophysical variables estimation of corn in Michigan. Agron. J. 97:99-105.

Feng, W., X. Yao, Y Zhu, Y.C. Tian, and W. Cao. 2008. Monitoring leaf nitrogen status with hyperspectral reflectance in wheat. European J. Agron. 28:394-404.

Freitas, J.R. 2000. Yield and $\mathrm{N}$ assimilation of winter wheat (Triticum aestivum L., var. Norstar) inoculated with rhizobacteria. Pedobiologia 44:97-104.

Galvão, L.S., A.R. Formaggio, and D.A. Tisot. 2005. Discrimination of sugarcane varieties in southeastern Brazil Hyperion data. Remote Sens. Environ. 94:523-534.

Galvão, L.S., D.A. Roberts, A.R. Formaggio, I. Numata, and F.M. Breunig. 2009. View angle effects on the discrimination of soybean varieties and on the relationships between vegetation indices and yield using off-nadir Hyperion data. Remote Sens. Environ. 113:846-856.

Gao, B. 1996. NDWI - A normalized difference water index for remote sensing of vegetation liquid water from space. Remote Sens. Environ. 58:257-266.

Goel, N.S. 1988. Models of vegetation canopy reflectance and their use in estimation of biophysical parameters from reflectance data. Remote Sens. Rev. 4:1-212. 
Kizilkaya, R. 2008. Yield response and nitrogen concentrations of spring wheat (Triticum aestivum) inoculated with Azotobacter Chroococcum strains. Ecological Eng. 33:150156.

Kokaly, R.F., and R.N Clark. 1999. Spectroscopic determination of leaf biochemistry using band-depth analysis of absorption features and stepwise multiple linear regression. Remote Sens. Environ. 67:267-287.

Large, E.C. 1954. Growth stages in cereals illustration of the Feekes scale. Plant Pathol. 3:128-129.

Larran, S., A. Perelló, M.R. Simón, and V. Moreno. 2007. The endophytic fungi from wheat (Triticum aestivum L.). World J. Microbiol. Biotechnol. 23:565-572.

LI-COR Biosciences Inc. LAI-2000, 2006. Available at http://www.licor.com/LAI (verified 3 Aug. 2006).

Meer, F.V. 2000. Spectral curve shape matching with a continuum removal CCSM algorithm. Int. J. Remote Sens. 21:3179-3185.

Milton, E.J. 1987. Principles of field spectroscopy. Int. J. Remote Sens. 8:1807-1827.

Mullen, R.W., K.W. Freeman, W.R. Raun, G.V. Johnson, M.L. Stone, and J.B Solie. 2003 Identifying an in-season response index and the potential to increase wheat yield with nitrogen. Agron. J. 95:347-351.

Mutanga, O., A.K. Skidmore, L. Kumar, and J. Ferwerda. 2005. Estimating tropical pasture quality at canopy level using band depth analysis with continuum removal in the visible domain. Int. J. Remote Sens. 26:1093-1108.

Mutanga, O., A.K. Skidmore, and S. Wieren. 2003. Discriminating tropical grass (Cenchrus ciliaris) canopies grown under different nitrogen treatments using spectroradiometry. ISPRS J. Photogramm. Remote Sens. 57:263-272.

Noomem, M.F., F.D. Meer, and A.K. Skidmore. 2005. Hyperspectral remote sensing for detecting the effects of three hydrocarbon gases on maize reflectance. $31^{\text {th }}$ International Symposium of Remote Sensing of Environment. St. Petersburg, 20-24 June, 2005.

Pu, R. S. Ge, N.M. Kelly, and P. Gong. 2003. Spectral absorption features as indicators of water status in coast live oak (Quercus agrifolia) leaves. Int. J. Remote Sens. 24:17991810. 
Pena-Yewtukhiw, E.M., G.J. Schwab, and L.W. Murdock. 2006. Univariate distribution analysis to evaluate variable rate fertilization. Agron. J. 98:554-561.

Raij, B. van, H. Cantarella, J.A. Quaggio, and A.M.C Furlani. 1997. Recomendações de Adubação e Calagem para o Estado de São Paulo (Boletim, 100). Instituto Agronômico de Campinas, Campinas, SP.

Raun, W.R., J.B. Solie, R.K. Taylor, D.B. Arnall, C.J. Mack, and D.E. Edmonds. 2008. Ramp calibration strip technology for determining midseason nitrogen rates in corn and wheat. Agron. J. 100:1088-1093.

Rodrigues, O., A.D. Didonet, J.A. Gouveia, and R.C. Soares. 2000. Nitrogen translocation in wheat inoculated with Azospirillum and fertilized with nitrogen. (In Portuguese, with English abstract.) Pesq. Agropec. Bras. 35:1473-1481.

Sala, V.M.R., E.J.B.N.Cardoso, J.G. Freitas, and A.P.D. Silveira. 2007. Response of wheat genotypes to inoculation with diazotrophic bacteria under field conditions. (In Portuguese, with English abstract.) Pesq. Agropec. Bras. 42:833-842.

Sala, V.M.R., S.S. Freitas, V.P. Donzeli, J.G. Freitas, P.B. Gallo, and A.P.D. Silveira. 2005. Occurrence and effect of diazotrophic bacteria on wheat genotypes. (In Portuguese, with English abstract.) Rev. Bras. Ciência Solo. 29:345-352.

Schmidt, K.S., and A.K. Skidmore. 2003. Spectral discrimination of vegetation types in a coastal wetland. Remote Sens. Environ. 85:92-108.

Serrano, L., I. Filella, and J. Penuelas. 2000. Remote sensing of biomass and yield of winter wheat under different nitrogen supplies. Crop Science 40:723-731.

Shou, L., L.L. Jia, Z.L. Cui, X.P. Chen, and F.S. Zhang. 2007. Using high-resolution satellite imaging to evaluate nitrogen status of winter wheat. J. Plant Nutrition 30:1669-1680.

Sripada, R.P., D.C. Farrer, R. Weisz, R.W. Heiniger, and J.G. White. 2007. Aerial color infrared photography to optimize in-season nitrogen fertilizer recommendations in winter wheat. Agron. J. 99:1424-1435.

Thenkabail, P.S., R.B. Smith, and E. Pauw. 2000. Hyperspectral vegetation indices and their relationships with agricultural crop characteristics. Remote Sens. Environ. 71:158-182.

Tilling, A.K., G.J. O’Leary, J.G. Ferwerda, S.D. Jones, G.J. Fitzgerald, D. Rodriguez, and R. Belford. 2007. Remote sensing of nitrogen and water stress in wheat. Field Crops Res. 104:77-85. 
Wiegand, C.L., A.J. Richardson, D.E. Escobar, and A.H. Gerbermann. 1991. Vegetation indices in crop assessments. Remote Sens. Environ. 35:105-119.

Wu, C.Y., Z. Niu, Q. Tang, and W.J. Huang. 2008. Estimating chlorophyll content from hyperspectral vegetation indices: Modeling and validation. Agric. For. Meteo. 148:12301241.

Zhao, C.J., Q. Zhou, J. Wang, and W.J. Huang. 2004. Band selection for analysing wheat water status under field conditions using relative depth indices (RDI). Int. J. Remote Sens. 25:2575-2584.

\section{LIST OF FIGURES}

Figure 1 - Schematic representation of the continuum removal. a) Reflectance spectrum of green vegetation; b) Continuum lines delimiting the edges of the three studied absorption bands (chlorophyll at $665 \mathrm{~nm}$; leaf water at $980 \mathrm{~nm}$ and $1205 \mathrm{~nm}$ ); and c) Normalized reflectance spectrum after continuum removal to isolate the absorption bands and to allow subsequent calculation of their depth and area. Source: Adapted from Pu et al. (2003).

Figure 2 - Frequency of the correlation coefficients from bootstrap analysis for the relationships of LAI with band depth $\left(P_{B}\right)$ values of the $665 \mathrm{~nm}, 982 \mathrm{~nm}$ and $1205 \mathrm{~nm}$ absorption bands and with NDVI for the: (a) jointing; (b) heading; and (c) ripening wheat growth stages.

Figure 3 - Frequency of the correlation coefficients from bootstrap analysis for the relationships of LAI with area $\left(A_{B}\right)$ values of the $665 \mathrm{~nm}, 982 \mathrm{~nm}$ and $1205 \mathrm{~nm}$ absorption bands and with NDVI for the: (a) jointing; (b) heading; and (c) ripening wheat growth stages.

Figure 4 - Frequency of the correlation coefficients from bootstrap analysis for the relationships of grain yield with band depth $\left(P_{B}\right)$ values of the $665 \mathrm{~nm}, 982 \mathrm{~nm}$ and $1205 \mathrm{~nm}$ absorption bands and with NDVI for the: (a) jointing; (b) heading; and (c) ripening wheat growth stages.

Figure 5 - Frequency of the correlation coefficients from bootstrap analysis for the relationships of grain yield with area $\left(A_{B}\right)$ values of the $665 \mathrm{~nm}, 982 \mathrm{~nm}$ and $1205 \mathrm{~nm}$ absorption bands and with NDVI for the: (a) jointing; (b) heading; and (c) ripening wheat growth stages. 
Table 1. Upper and lower limits of absorption bands and $\lambda_{\text {reference }}$ for continuum removal.

\begin{tabular}{lrrrc}
\hline & Lower limit $(m)$ & Upper limit $(M)$ & \multicolumn{1}{c}{$\lambda_{\text {reference }}$} & Associated components \\
\hline $1^{\text {st }}$. absorption band & $550 \mathrm{~nm}$ & $720 \mathrm{~nm}$ & $665 \mathrm{~nm}$ & Chlorophyll \\
$2^{\text {nd }}$. absorption band & $950 \mathrm{~nm}$ & $1015 \mathrm{~nm}$ & $982 \mathrm{~nm}$ & Water \\
$3^{\text {rd }}$. absorption band & $1140 \mathrm{~nm}$ & $1260 \mathrm{~nm}$ & $1205 \mathrm{~nm}$ & Water \\
\hline
\end{tabular}

Table 2. Analysis of variance for the LAI and grain yield $\left(\mathrm{kg} \mathrm{ha}^{-1}\right)$

\begin{tabular}{|c|c|c|c|c|c|c|c|c|c|}
\hline \multirow{3}{*}{ Factors } & \multirow{3}{*}{$n$} & \multicolumn{6}{|c|}{ LAI } & \multirow{2}{*}{\multicolumn{2}{|c|}{$\begin{array}{l}\text { Grain yield } \\
\mathrm{kg} \mathrm{ha}^{-1}\end{array}$}} \\
\hline & & \multicolumn{2}{|c|}{$\begin{array}{c}21 / 07 / 2006 \\
\text { jointing }\end{array}$} & \multicolumn{2}{|c|}{$\begin{array}{c}04 / 08 / 2006 \\
\text { heading }\end{array}$} & \multicolumn{2}{|c|}{$\begin{array}{c}21 / 08 / 2006 \\
\text { ripening }\end{array}$} & & \\
\hline & & Mean & S.D. & Mean & S.D. & Mean & S.D. & Mean & S.D. \\
\hline B0 & 18 & $3.79 \mathrm{NS}$ & 1.36 & $3.55 \mathrm{NS}$ & 0.82 & $3.34 \mathrm{NS}$ & 0.79 & 2949 a & 847.7 \\
\hline B1 & 18 & $3.79 \mathrm{NS}$ & 1.55 & $3.64 \mathrm{NS}$ & 1.05 & $3.46 \mathrm{NS}$ & 0.96 & $3225 \mathrm{~b}$ & 984.8 \\
\hline B2 & 18 & $4.04 \mathrm{NS}$ & 1.47 & $3.61 \mathrm{NS}$ & 0.98 & $3.67 \mathrm{NS}$ & 0.98 & $3452 \mathrm{~b}$ & 700.1 \\
\hline B3 & 18 & $3.72 \mathrm{NS}$ & 1.36 & $3.57 \mathrm{NS}$ & 0.97 & $3.93 \mathrm{NS}$ & 1.19 & $3237 \mathrm{~b}$ & 998.9 \\
\hline No & 24 & $2.45 \mathrm{a}$ & 0.75 & $2.69 \mathrm{a}$ & 0.49 & $2.91 \mathrm{a}$ & 0.79 & $2107 \mathrm{a}$ & 428.5 \\
\hline N60 & 24 & $4.20 \mathrm{~b}$ & 1.17 & $3.70 \mathrm{~b}$ & 0.61 & $3.65 \mathrm{~b}$ & 0.59 & $3498 \mathrm{~b}$ & 288.9 \\
\hline \multirow[t]{2}{*}{ N120 } & 24 & $4.86 \mathrm{~b}$ & 1.00 & $4.39 \mathrm{c}$ & 0.77 & $4.24 \mathrm{~b}$ & 1.08 & $4041 \mathrm{c}$ & 322.3 \\
\hline & & $\mathrm{F}$ test & $p$-value & $\mathrm{F}$ test & $p$-value & $\mathrm{F}$ test & $p$-value & $\mathrm{F}$ test & $p$-value \\
\hline Bacteria (a) & & 0.32 & 0.81 & 0.07 & 0.97 & 1.79 & 0.16 & 9.17 & $<0.01^{* *}$ \\
\hline Nitrogen (b) & & 34.84 & $<0.01 * *$ & 38.89 & $<0.01^{* *}$ & 15.91 & $<0.01 * *$ & 287.00 & $<0.01 * *$ \\
\hline Interaction $(\mathrm{a} X \mathrm{~b})$ & & 0.30 & 0.93 & 0.27 & 0.95 & 1.36 & 0.24 & 2.50 & $0.03 *$ \\
\hline
\end{tabular}

*, ** Significant at the 5\% and 1\% levels, respectively; NS - not significant: values followed by the same letter do not differ from each other at the $5 \%$ probability level. 
Table 3. Analysis of the interaction between bacteria and Nitrogen $(\mathrm{N})$ for grain yield $\left(\mathrm{kg} \mathrm{ha}^{-1}\right)$.

\begin{tabular}{ccc}
\hline Bacteria & $\mathrm{N}$ & Grain yield $^{\mathrm{a}}$ \\
\hline B0 & $\mathrm{N} 0$ & $1832 \mathrm{a}$ \\
B1 & $\mathrm{N} 0$ & $2046 \mathrm{a}, \mathrm{b}$ \\
B2 & $\mathrm{N} 0$ & $2568 \mathrm{~b}$ \\
B3 & $\mathrm{N} 0$ & $1983 \mathrm{a}$ \\
B0 & $\mathrm{N} 60$ & $3320 \mathrm{c}$ \\
B1 & $\mathrm{N} 60$ & $3455 \mathrm{c}$ \\
B2 & $\mathrm{N} 60$ & $3750 \mathrm{c}, \mathrm{d}$ \\
B3 & $\mathrm{N} 60$ & $3467 \mathrm{c}$ \\
B0 & $\mathrm{N} 120$ & $3696 \mathrm{c}, \mathrm{d}$ \\
B1 & $\mathrm{N} 120$ & $4173 \mathrm{~d}$ \\
B2 & $\mathrm{N} 120$ & $4037 \mathrm{~d}$ \\
B3 & $\mathrm{N} 120$ & $4260 \mathrm{~d}$ \\
\hline
\end{tabular}

${ }^{\text {a }}$ Means followed by the same letter do not differ significantly at the $5 \%$ level. 
Table 4. Analysis of variance for area $\left(A_{B}\right)$ values of the absorption bands centered at $665 \mathrm{~nm}$, $982 \mathrm{~nm}$ and $1205 \mathrm{~nm}$.

\begin{tabular}{|c|c|c|c|c|c|c|c|}
\hline \multicolumn{8}{|c|}{$A_{B} 665 \mathrm{~nm}$} \\
\hline \multirow[t]{2}{*}{ Factors } & \multirow[t]{2}{*}{$n$} & \multicolumn{2}{|c|}{$\begin{array}{c}\text { 21/07/2006 } \\
\text { jointing }\end{array}$} & \multicolumn{2}{|c|}{$\begin{array}{c}\text { 04/08/2006 } \\
\text { heading }\end{array}$} & \multicolumn{2}{|c|}{$\begin{array}{c}\text { 21/08/2006 } \\
\text { ripening }\end{array}$} \\
\hline & & Mean & S.D. & Mean & S.D. & Mean & S.D. \\
\hline No & 24 & $99.22 \mathrm{a}$ & 4.34 & $86.65 \mathrm{a}$ & 8.04 & $58.08 \mathrm{a}$ & 13.12 \\
\hline N60 & 24 & $105.04 \mathrm{~b}$ & 2.64 & $102.82 \mathrm{~b}$ & 3.76 & $71.39 \mathrm{~b}$ & 9.09 \\
\hline N120 & 24 & $108.17 \mathrm{c}$ & 1.59 & $104.94 \mathrm{~b}$ & 2.26 & $74.27 \mathrm{~b}$ & 9.85 \\
\hline Analysis of variance & & $\mathrm{F}$ test & $p$-value & F test & $p$-value & F test & $p$-value \\
\hline Bacteria (a) & & 2.04 & 0.12 & 0.30 & 0.83 & 0.13 & 0.94 \\
\hline Nitrogen (b) & & 24.86 & $<0.01 * *$ & 23.15 & $<0.01 * *$ & 6.82 & $<0.01 * *$ \\
\hline Interaction $(\mathrm{a} X \mathrm{~b})$ & & 0.35 & 0.91 & 1.35 & 0.25 & 0.33 & 0.92 \\
\hline \multicolumn{8}{|c|}{$A_{B} 982 \mathrm{~nm}$} \\
\hline \multirow[t]{2}{*}{ Factors } & \multirow[t]{2}{*}{$n$} & \multicolumn{2}{|c|}{$\begin{array}{c}\text { 21/07/2006 } \\
\text { jointing }\end{array}$} & \multicolumn{2}{|c|}{$\begin{array}{c}\text { 04/08/2006 } \\
\text { heading }\end{array}$} & \multicolumn{2}{|c|}{$\begin{array}{l}\text { 21/08/2006 } \\
\text { ripening }\end{array}$} \\
\hline & & Mean & S.D. & Mean & S.D. & Mean & S.D. \\
\hline No & 24 & $1.50 \mathrm{a}$ & 0.45 & $1.63 \mathrm{a}$ & 0.71 & $1.44 \mathrm{a}$ & 0.7 \\
\hline N60 & 24 & $1.92 \mathrm{~b}$ & 0.41 & $2.36 \mathrm{~b}$ & 0.47 & $2.05 \mathrm{~b}$ & 0.52 \\
\hline N120 & 24 & $2.27 \mathrm{c}$ & 0.24 & $2.62 \mathrm{~b}$ & 0.31 & $2.03 \mathrm{~b}$ & 0.63 \\
\hline Analysis of variance & & $\mathrm{F}$ test & $p$-value & $\mathrm{F}$ test & $p$-value & $\mathrm{F}$ test & $p$-value \\
\hline Bacteria (a) & & 0.50 & 0.68 & 0.12 & 0.95 & 0.08 & 0.97 \\
\hline Nitrogen (b) & & 34.51 & $<0.01 * *$ & 46.01 & $<0.01 * *$ & 12.00 & $<0.01 * *$ \\
\hline Interaction (a X b) & & 0.38 & 0.89 & 1.83 & 0.11 & 0.39 & 0.88 \\
\hline \multicolumn{8}{|c|}{$A_{B} 1205 \mathrm{~nm}$} \\
\hline \multirow[t]{2}{*}{ Factors } & \multirow[t]{2}{*}{$n$} & \multicolumn{2}{|c|}{$\begin{array}{c}\text { 21/07/2006 } \\
\text { jointing }\end{array}$} & \multicolumn{2}{|c|}{$\begin{array}{c}\text { 04/08/2006 } \\
\text { heading }\end{array}$} & \multicolumn{2}{|c|}{$\begin{array}{c}\text { 21/08/2006 } \\
\text { ripening }\end{array}$} \\
\hline & & Mean & S.D. & Mean & S.D. & Mean & S.D. \\
\hline N0 & 24 & $6.27 \mathrm{a}$ & 0.77 & $6.38 \mathrm{a}$ & 1.09 & $5.44 \mathrm{a}$ & 1.7 \\
\hline N60 & 24 & $7.08 \mathrm{~b}$ & 0.51 & $8.21 \mathrm{~b}$ & 0.87 & $7.08 \mathrm{~b}$ & 1.2 \\
\hline N120 & 24 & $7.84 \mathrm{c}$ & 0.58 & $8.81 \mathrm{~b}$ & 0.81 & $7.37 \mathrm{~b}$ & 1.25 \\
\hline Analysis of variance & & F test & $p$-value & F test & $p$-value & F test & $p$-value \\
\hline Bacteria (a) & & 0.51 & 0.68 & 0.28 & 0.84 & 0.20 & 0.90 \\
\hline Nitrogen (b) & & 47.73 & $<0.01 * *$ & 79.51 & $<0.01 * *$ & 13.93 & $<0.01 * *$ \\
\hline Interaction $(\mathrm{a} \mathrm{X} \mathrm{b)}$ & & 0.19 & 0.98 & 0.51 & 0.80 & 0.40 & 0.88 \\
\hline
\end{tabular}

*, ** Significant at the $5 \%$ and $1 \%$ levels, respectively; NS = not significant; values followed by the same letter do not differ from each other at the $5 \%$ probability level. 
1

Table 5. Analysis of variance for depth $\left(P_{B}\right)$ values of the absorption bands centered at 665 $\mathrm{nm}, 982 \mathrm{~nm}$ and $1205 \mathrm{~nm}$.

\begin{tabular}{|c|c|c|c|c|c|c|c|}
\hline \multicolumn{8}{|c|}{$P_{B} 665 \mathrm{~nm}$} \\
\hline \multirow[t]{2}{*}{ Factors } & \multirow[t]{2}{*}{$n$} & \multicolumn{2}{|c|}{$\begin{array}{c}\text { 21/07/2006 } \\
\text { jointing }\end{array}$} & \multicolumn{2}{|c|}{$\begin{array}{c}\text { 04/08/2006 } \\
\text { heading }\end{array}$} & \multicolumn{2}{|c|}{$\begin{array}{c}21 / 08 / 2006 \\
\text { ripening }\end{array}$} \\
\hline & & Mean & S.D. & Mean & S.D. & Mean & S.D. \\
\hline No & 24 & $0.877 \mathrm{a}$ & 0.0193 & $0.796 \mathrm{a}$ & 0.0449 & $0.559 \mathrm{a}$ & 0.0948 \\
\hline N60 & 24 & $0.897 \mathrm{~b}$ & 0.0107 & $0.868 \mathrm{~b}$ & 0.0148 & $0.654 \mathrm{~b}$ & 0.0628 \\
\hline N120 & 24 & $0.901 \mathrm{~b}$ & 0.0101 & $0.864 \mathrm{~b}$ & 0.0087 & $0.672 \mathrm{~b}$ & 0.0695 \\
\hline Analysis of variance & & F test & $p$-value & F test & $p$-value & F test & $p$-value \\
\hline Bacteria (a) & & 2.07 & 0.11 & 0.23 & 0.88 & 0.39 & 0.76 \\
\hline Nitrogen (b) & & 20.32 & $<0.01 * *$ & 23.05 & $<0.01 * *$ & 4.33 & $0.02 *$ \\
\hline Interaction $(\mathrm{a} \mathrm{X} \mathrm{b)}$ & & 0.51 & 0.8 & 1.02 & 0.42 & 0.44 & 0.85 \\
\hline \multicolumn{8}{|c|}{$P_{B} 982 \mathrm{~nm}$} \\
\hline \multirow[t]{2}{*}{ Factors } & \multirow[t]{2}{*}{$\mathrm{n}$} & \multicolumn{2}{|c|}{$\begin{array}{c}21 / 07 / 2006 \\
\text { jointing }\end{array}$} & \multicolumn{2}{|c|}{$\begin{array}{c}\text { 04/08/2006 } \\
\text { heading }\end{array}$} & \multicolumn{2}{|c|}{$\begin{array}{c}\text { 21/08/2006 } \\
\text { ripening }\end{array}$} \\
\hline & & Mean & S.D. & Mean & S.D. & Mean & S.D. \\
\hline N0 & 24 & $0.039 \mathrm{a}$ & 0.0090 & $0.043 \mathrm{a}$ & 0.0143 & $0.039 \mathrm{a}$ & 0.0157 \\
\hline N60 & 24 & $0.047 \mathrm{~b}$ & 0.0097 & $0.058 \mathrm{~b}$ & 0.0086 & $0.051 \mathrm{~b}$ & 0.0138 \\
\hline N120 & 24 & $0.054 \mathrm{~b}$ & 0.0064 & $0.063 \mathrm{~b}$ & 0.0068 & $0.050 \mathrm{~b}$ & 0.0153 \\
\hline Analysis of variance & & $\mathrm{F}$ test & $p$-value & F test & $p$-value & F test & $p$-value \\
\hline Bacteria (a) & & 0.74 & 0.53 & 0.14 & 0.94 & 0.07 & 0.98 \\
\hline Nitrogen (b) & & 38.18 & $<0.01 * *$ & 48.6 & $<0.01 * *$ & 11.69 & $<0.01 * *$ \\
\hline Interaction $(\mathrm{a} X \mathrm{~b})$ & & 0.43 & 0.86 & 1.86 & 0.1 & 0.36 & 0.9 \\
\hline \multicolumn{8}{|c|}{$P_{B} 1205 \mathrm{~nm}$} \\
\hline \multirow[t]{2}{*}{ Factors } & \multirow[t]{2}{*}{$n$} & \multicolumn{2}{|c|}{$\begin{array}{c}\text { 21/07/2006 } \\
\text { jointing }\end{array}$} & \multicolumn{2}{|c|}{$\begin{array}{c}\text { 04/08/2006 } \\
\text { heading }\end{array}$} & \multicolumn{2}{|c|}{$\begin{array}{c}\text { 21/08/2006 } \\
\text { ripening }\end{array}$} \\
\hline & & Mean & S.D. & Mean & S.D. & Mean & S.D. \\
\hline N0 & 24 & $0.080 \mathrm{a}$ & 0.0091 & $0.082 \mathrm{a}$ & 0.0130 & $0.070 \mathrm{a}$ & 0.0210 \\
\hline N60 & 24 & $0.091 \mathrm{~b}$ & 0.0064 & $0.105 \mathrm{~b}$ & 0.0102 & $0.090 \mathrm{~b}$ & 0.0149 \\
\hline N120 & 24 & $0.100 \mathrm{c}$ & 0.0070 & $0.111 \mathrm{~b}$ & 0.0099 & $0.093 \mathrm{~b}$ & 0.0156 \\
\hline Analysis of variance & & F test & $p$-value & F test & $p$-value & F test & $p$-value \\
\hline Bacteria (a) & & 0.5 & 0.66 & 0.45 & 0.72 & 0.2 & 0.9 \\
\hline Nitrogen (b) & & 18.4 & $<0.01 * *$ & 46.59 & $<0.01 * *$ & 13.69 & $<0.01 * *$ \\
\hline Interaction $(\mathrm{a} X \mathrm{~b})$ & & 0.2 & 0.99 & 0.3 & 0.93 & 0.35 & 0.91 \\
\hline
\end{tabular}

*, ** Significant at the 5\% and $1 \%$ levels, respectively; NS = not significant; values followed by the same letter do not differ from each other at the $5 \%$ probability level. 
Table 6. Analysis of variance for NDVI values.

\begin{tabular}{|c|c|c|c|c|c|c|c|}
\hline \multicolumn{8}{|c|}{ NDVI } \\
\hline \multirow[t]{2}{*}{ Factors } & \multirow[t]{2}{*}{$n$} & \multicolumn{2}{|c|}{$\begin{array}{c}21 / 07 / 2006 \\
\text { jointing }\end{array}$} & \multicolumn{2}{|c|}{$\begin{array}{c}\text { 04/08/2006 } \\
\text { heading }\end{array}$} & \multicolumn{2}{|c|}{$\begin{array}{c}21 / 08 / 2006 \\
\text { ripening }\end{array}$} \\
\hline & & Mean & S.D. & Mean & S.D. & Mean & S.D. \\
\hline No & 24 & $0.89 \mathrm{a}$ & 0.02 & $0.82 \mathrm{a}$ & 0.05 & $0.65 \mathrm{a}$ & 0.11 \\
\hline N60 & 24 & $0.92 \mathrm{~b}$ & 0.01 & $0.92 \mathrm{~b}$ & 0.02 & $0.76 \mathrm{~b}$ & 0.08 \\
\hline N120 & 24 & $0.94 \mathrm{c}$ & 0.01 & $0.93 \mathrm{~b}$ & 0.01 & $0.79 \mathrm{~b}$ & 0.07 \\
\hline Analysis of variance & & F test & $p$-value & F test & $p$-value & F test & $p$-value \\
\hline Bacteria (a) & & 0.6 & 0.6 & 0.24 & 0.87 & 0.15 & 0.93 \\
\hline Nitrogen (b) & & 43.5 & $<0.01 * *$ & 69.06 & $<0.01 * *$ & 15.21 & $<0.01 * *$ \\
\hline Interaction (a X b) & & 0.3 & 0.95 & 0.37 & 0.9 & 0.49 & 0.82 \\
\hline
\end{tabular}

*, ** Significant at the 5\% and $1 \%$ levels, respectively; NS = not significant; values followed by the same letter do not differ from each other at the $5 \%$ probability level.

Table 7. Mean correlation coefficients from bootstrap analysis for the relationships of grain yield and LAI with absorption band depth $\left(P_{B}\right)$, area $\left(A_{B}\right)$ and NDVI values.

\begin{tabular}{lccc}
\hline Spectral Parameter & $\begin{array}{c}21 / 07 / 2006 \\
\text { jointing }\end{array}$ & $\begin{array}{c}04 / 08 / 2006 \\
\text { heading }\end{array}$ & $\begin{array}{c}21 / 08 / 2006 \\
\text { ripening }\end{array}$ \\
\hline & & LAI & \\
\hline$P_{B} 665 \mathrm{~nm}$ & 0.58 & 0.70 & 0.58 \\
$A_{B} 665 \mathrm{~nm}$ & 0.76 & 0.82 & 0.58 \\
$P_{B} 982 \mathrm{~nm}$ & 0.52 & 0.66 & 0.37 \\
$A_{B} 982 \mathrm{~nm}$ & 0.57 & 0.69 & 0.41 \\
$P_{B} 1205 \mathrm{~nm}$ & 0.73 & 0.80 & 0.54 \\
$A_{B} 1205 \mathrm{~nm}$ & 0.72 & 0.80 & 0.55 \\
NDVI & 0.75 & 0.81 & 0.58 \\
\hline & & Yield & \\
\hline$P_{B} 665 \mathrm{~nm}$ & 0.54 & 0.72 & 0.53 \\
$A_{B} 665 \mathrm{~nm}$ & 0.54 & 0.71 & 0.54 \\
$P_{B} 982 \mathrm{~nm}$ & 0.38 & 0.70 & 0.43 \\
$A_{B} 982 \mathrm{~nm}$ & 0.46 & 0.70 & 0.46 \\
$P_{B} 1205 \mathrm{~nm}$ & 0.49 & 0.74 & 0.51 \\
$A_{B} 1205 \mathrm{~nm}$ & 0.50 & 0.73 & 0.52 \\
NDVI & 0.54 & 0.72 & 0.53 \\
\hline
\end{tabular}




\section{Page 21 of 25}

6

7

8

9

10

11

12

13

14

15

16

17

18

19

20

Figure 1 - Schematic representation of the continuum removal. a) Reflectance spectrum of green vegetation; b) Continuum lines delimiting the edges of the three studied absorption bands (chlorophyll at $665 \mathrm{~nm}$; leaf water at $980 \mathrm{~nm}$ and $1205 \mathrm{~nm}$ ); and c) Normalized reflectance spectrum after continuum removal to isolate the absorption bands and to allow subsequent calculation of their depth and area. Source: Adapted from Pu et al. (2003). 

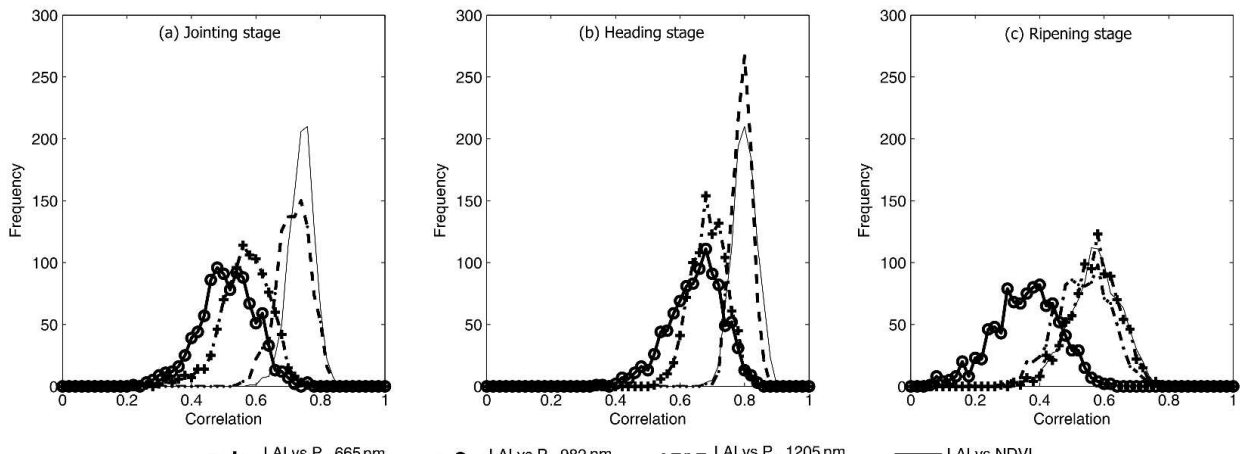

Figure 2 - Frequency of the correlation coefficients from bootstrap analysis for the relationships of LAI with band depth (PB) values of the $665 \mathrm{~nm}, 982 \mathrm{~nm}$ and $1205 \mathrm{~nm}$ absorption bands and with NDVI for the: (a) jointing; (b) heading; and (c) ripening wheat growth stages. 


\section{Page 23 of 25}
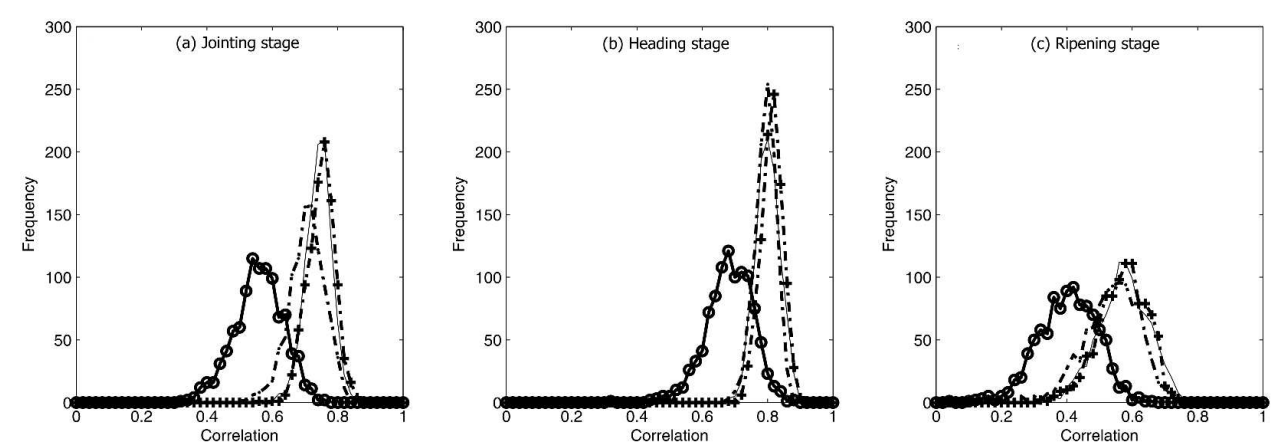

+- LAI vs $A_{B} 665 n$ m

- LAI vs $A_{B} 982 \mathrm{~nm}$

...- LAl vs $A_{B} 1205 \mathrm{~nm}$

LAI vs NDVI

Figure 3 - Frequency of the correlation coefficients from bootstrap analysis for the relationships of LAI with area $(A B)$ values of the $665 \mathrm{~nm}, 982 \mathrm{~nm}$ and $1205 \mathrm{~nm}$ absorption bands and with NDVI for the: (a) jointing; (b) heading; and (c) ripening wheat growth stages. 

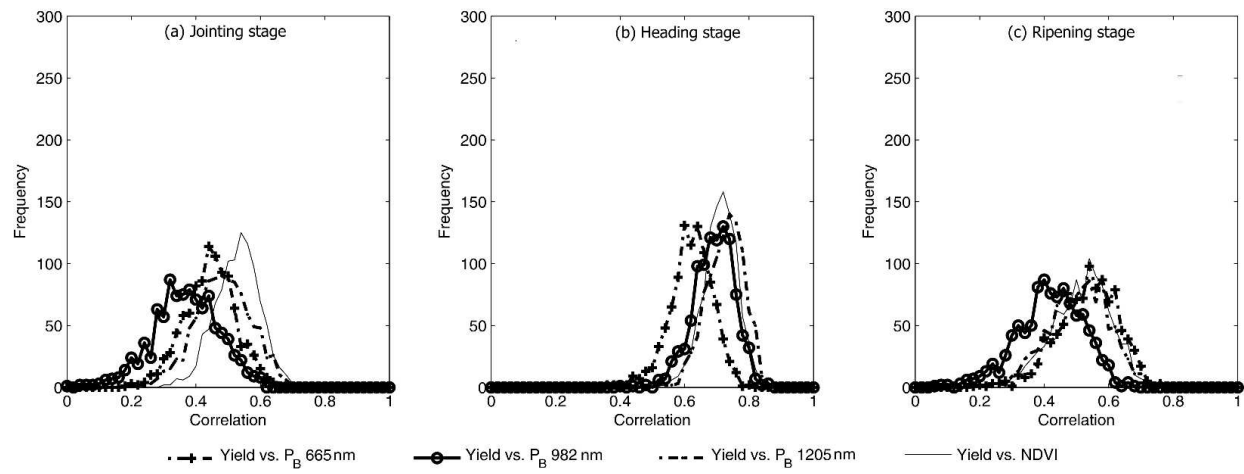

Figure 4 - Frequency of the correlation coefficients from bootstrap analysis for the relationships of grain yield with band depth (PB) values of the $665 \mathrm{~nm}, 982 \mathrm{~nm}$ and $1205 \mathrm{~nm}$ absorption bands and with NDVI for the: (a) jointing; (b) heading; and (c) ripening wheat growth stages. 


\section{Page 25 of 25}
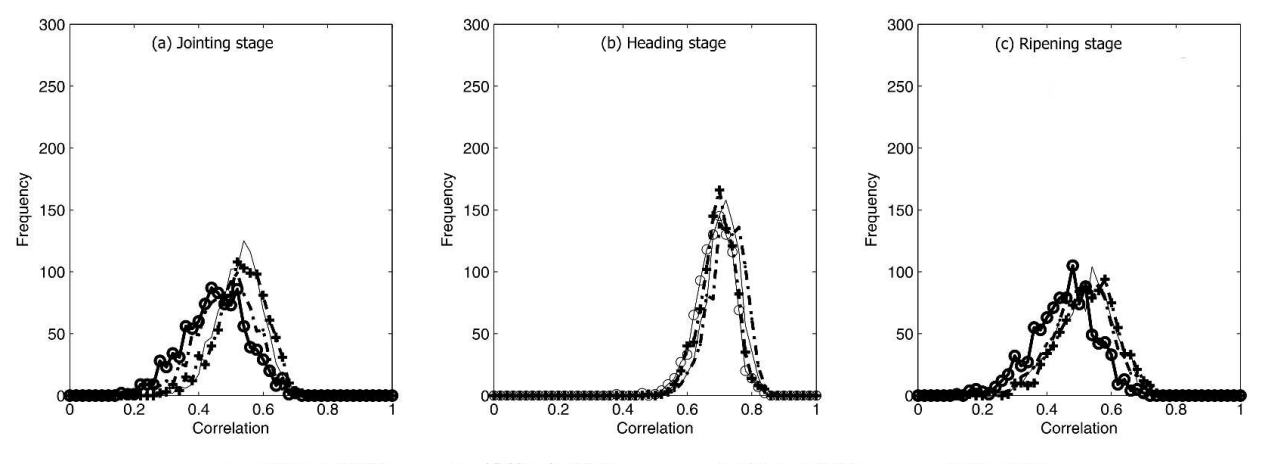

$\cdot \rightarrow-$ Yield vs $A_{B} 665 \mathrm{~nm}$

$\rightarrow$ Yield vs $A_{B} 982 \mathrm{~nm} \quad$...- Yield vs $A_{B} 1205 n$

Yield vs NDVI

Figure 5 - Frequency of the correlation coefficients from bootstrap analysis for the relationships of grain yield with area (AB) values of the $665 \mathrm{~nm}, 982 \mathrm{~nm}$ and $1205 \mathrm{~nm}$ absorption bands and with NDVI for the: (a) jointing; (b) heading; and (c) ripening wheat growth stages. 